Gut, 1974, 15, 875-879

\title{
Localization of calcium-binding protein in intestinal tissue by immunofluorescence in normal, vitamin-D-deficient and uraemic subjects
}

\author{
K. HelmKe, K. FEderlin, P. PiAzolo, J. Ströder, R. JESCHKe, AND \\ H. E. FRANZ 1 \\ From the Department of Medicine, University of Ulm, and the Children's Hospital, University of Würzburg, \\ Federal Republic of Germany
}

SUMMARY Antiserum directed against calcium-binding protein isolated from human kidneys was used for the immunofluorescent localization of calcium-binding protein in human intestine and kidney. Frozen sections of intestine obtained by biopsy from normal persons were tested by the indirect fluorescent antibody technique. Specific fluorescence indicating the presence of calciumbinding protein was observed at both the basal and apical poles of the intestinal absorptive cells while the goblet cells appeared to fluoresce non-specifically. Treatment of rachitic children with 25 hydroxycholecalciferol generally restored the pattern of fluorescence seen in intestinal tissue from normal persons. Examinations of intestinal biopsies from uraemic patients yielded variable results.

A vitamin D-induced calcium-binding protein was originally detected in chicks by Wasserman and Taylor (1966) and Taylor and Wasserman (1970). Later, a similar intestinal Calcium-binding protein was detected in a variety of other species (Kallfelz, Taylor, and Wasserman, 1967; Taylor, Wasserman and Jowsey, 1968; Walling and Rothman, 1969; Wasserman and Taylor, 1970). Piazolo, Schleyer, and Franz (1971b) first reported its isolation from human kidney and intestinal tissue. Others have also isolated it from human intestine (Alpers, Lee, and Avioli, 1970; Hitchman, Finlay, and Harrison, 1971; Menczel, Eilon, Steiner, Karaman, Mor, and Ron, 1971) and partially characterized the protein. Many studies carried out with experimental animals have suggested that it is involved in the process of intestinal calcium transport (Wasserman and Taylor, 1966; Walling and Rothman, 1969; MacGregor, Hamilton, and Cohn, 1971). In support of that concept was the finding by Taylor and Wassermann (1970) that calcium-binding protein was situated at the absorptive surface of chick intestinal cells. This

${ }^{1}$ Please request reprints from Professor Dr H. E. Franz, Steinhorelstr. 9, D 79, Ulm, Federal Republic of Germany.

Received for publication 10 July 1974. report deals with its immunofluorescent localization in human intestine.

\section{Materials and Methods}

Small intestinal tissue was obtained by suction biopsy from 12 healthy persons (aged 30 to 60 years), from four rachitic babies (4 to 13 months), both before and after treatment with 25-hydroxycholecalciferol (baby 1, 4 months of age, $420 \mu \mathrm{g} \mathrm{25-HCC;}$ baby 2,13 months of age, $322 \mu \mathrm{g} \mathrm{HCC}$ and 100000 IE vitamin $\mathrm{D}_{3}$; baby 3,5 months of age, $250 \mu \mathrm{g}$ 25-HCC; baby 4, 10 months, 429000 IE vitamin $\mathrm{D}_{3}$ ), and from uraemic patients on chronic dialysis (30 to 65 years old). Portions of stomach, rectum, liver, lung, and skin from normal individuals were taken for examination. All samples were frozen on dry ice within 15 minutes after biopsy in the case of intestinal tissue and within 30 minutes for the other tissues. The anti-calcium-binding protein antiserum was prepared in rabbits by immunization with a highly purified calcium-binding protein (Piazolo, Schleyer, and Franz, 1971a and b) from human kidney tissue. Three $\mathrm{mg}$ of the protein was dissolved in $2 \mathrm{ml}$ of $0.9 \%$ sodium chloride solution and emulsified with $2 \mathrm{ml}$ of complete Freund's adjuvant. Injections were given simultaneously intra- and subcutaneously 
every two weeks for a period of eight to 12 weeks. At the time the rabbits were killed the serum was recovered and separated on Sephadex G-75 in order to obtain the $7 \mathrm{~S}$ gamma globulins. The specificity of the antibodies was tested by the Ouchterlony technique (1962), and the quantity determined by the Mancini technique (Mancini, Carbonara, and Heremans, 1965) and counterelectrophoresis as described by Piazolo (1973). Furthermore the Chelex 100 -test was used showing that the activity of calcium-binding protein was blocked by adding the specific antibody, whereas adding albumin or serum did not reduce the Ca-binding activity.

The frozen tissues were cut at $4 \mu$ for immunohistological treatment. No fixative was used which in our experience is superior to the use of chemical fixatives. The sections were thawed on the microscope slide and incubated at room temperature for 30 minutes with dilutions of the rabbit anti-calciumbinding protein $7 \mathrm{~S}$ gamma globulin solution. Antisera dilutions between 1:1 and 1:500 were tested and dilutions between 1:100 and 1:200 seemed to be optimal and therefore were used throughout the study. After incubation with the calcium-binding protein antibodies the sections were rinsed three

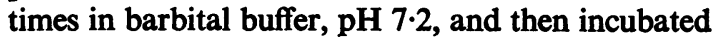
with FITC-labelled antirabbit serum from the goat (Behring Corp., Marburg, West Germany) for $\mathbf{3 0}$ minutes at room temperature. The commercial FITC-labelled antiserum was first purified by chromatography on DEAE-Sephadex 50 to remove the unbound FITC. After rinsing again three times with barbital buffer the sections were sealed with glycerine-phosphate buffer and examined under a Zeiss fluorescent microscope, BG 3/4 filter and BG 38/2.5 filter. The photomicrographs were taken with a Leitz camera and $16 \times$ to $63 \times$ enlarging objectives. Histological sections of tissues were also treated with the following reagents in place of the specific anti-calcium-binding protein antisera thus providing the necessary immunological controls: (1) Purified specific antibody which had been absorbed for $\mathbf{3 0}$ minutes with calcium-binding protein at $37^{\circ} \mathrm{C}$; (2) serum from an unimmunized rabbit; (3) serum from an unimmunized rabbit after absorption with calcium-bound protein; (4) FITClabelled antirabbit immunoglobulin; and (5) buffer solution.

Sections were also examined by the direct immunofluorescence method. They were incubated for half an hour with FITC-labelled antisera against $\operatorname{IgG}, \operatorname{IgA}, \operatorname{IgM}, C_{3}$, and IgE. Immunoglobulin-producing cells were counted and correlated. Furthermore the sections were examined for complexdeposits on the mucosa. No abnormal content or loss of immunoglobulins was found on immuno- globulin-producing cells, especially in the mucosa of the intestine.

\section{Results}

After incubation with the specific antibody there was fluorescence in the goblet cells and in the basal and apical parts of the mucosal cells (probably the brush borders) of normal small intestinal tissue (fig 1). After absorption of the antibody with calciumbinding protein in different concentrations, the fluorescence at the base and the apical part of the mucosal cells became weaker or disappeared, while the fluorescence of the goblet cells remained (fig 2), which would suggest that the goblet cell fluorescence was not specific. This was supported by the finding that the same result was obtained when specific antibody was replaced either by the serum of a unimmunized rabbit or after incubation with the antirabbit serum from the goat. Similar results were also obtained with FITC-labelled antiimmunoglobulin sera of other animal species.

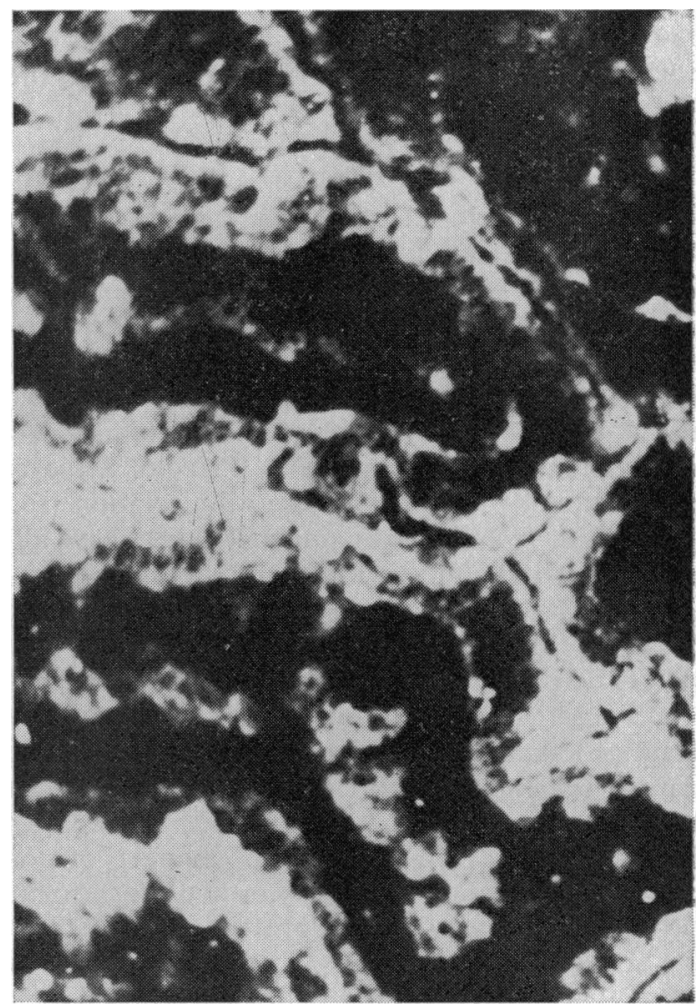

Fig 1 Calcium-binding protein in the duodenal mucosa: Strong fluorescence at the basement membrane, the apical part of the mucosal cells and the goblet cells ( $\times 40)$. 


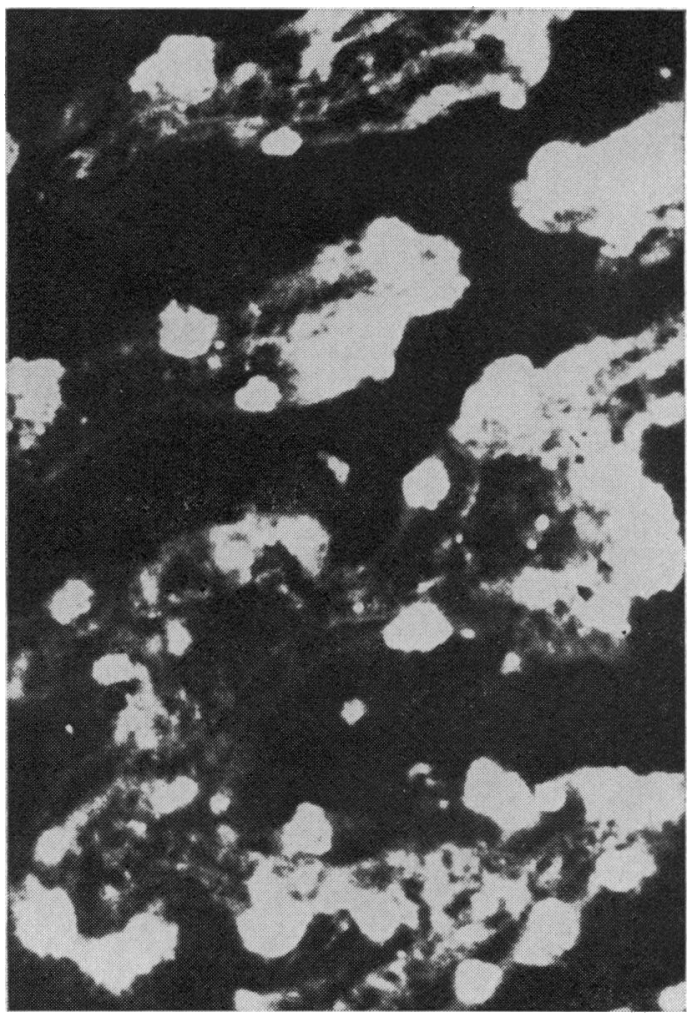

Fig 2 After adsorption with calcium-binding protein, fluorescence of the goblet cells only $(\times 40)$.

Biopsies of small intestinal tissue from rachitic children were examined before and after treatment with 25-hydroxychole-calciferol. Before treatment, one biopsy showed no fluorescence at all, two biopsies only weak fluorescence, and one biopsy showed normal fluorescence at the base and no fluorescence at the apical part of the mucosal cells. The biopsies after treatment, however, showed almost normal fluorescence in three cases while in one case fluorescence in the apical part of the mucosal cell was still missing. The fluorescence of the goblet cells was not altered by 25 -hydroxycholecalciferol treatment since, in two cases fluorescence was not seen before or after treatment and, in two other cases, it was seen both before and after treatment (fig 3).

Examination of uraemic small intestinal tissue yielded varying results. While one patient showed no difference from the normal, three biopsies showed a marked diminution of fluorescence in the apical part of the mucosal cell and in addition two of these less fluorescence than normal at the base of the mucosal cells (fig 4). The goblet cells in two cases showed unaltered fluorescence, and, in three other cases there was no fluorescence either after incubation with antibody or with control sera.

This result could not be reproduced with normal rabbit serum. Attempts to localize calcium-binding protein in stomach, colon, liver, lung, and the skin were negative. In all of these tissues, there was no specific fluorescence after incubation with antibodies against calcium-binding protein.

\section{Discussion}

Taylor and Wasserman (1970) were able to localize calcium-binding protein by immunofluorescence in the intestine of the chick. They found specific fluorescence in the PAS-positive goblet cells and at the surface of all intestinal epithelial cells. The resolution was not sufficiently precise to distinguish between microvilli and the surface coat material. In the same paper they demonstrated a lack of specific fluorescence in rachitic chicks as expected, due to the lack of calcium-binding protein in the vitamin D-deficient animals. After treatment with vitamin D, immunofluorescence specific for calcium-binding protein appeared.

We were able to localize calcium-binding protein by the method of indirect immunofluorescence in the mucosa of the small intestine in which there is considerable transepithelial transfer of calcium. The results are in agreement with those of Piazolo et al, (Piazolo, Schleyer, and Franz, 1971; Piazolo, 1973; Piazolo, Schleyer, Helmke, and Franz, 1974), who found a high concentration in this tissue by immunochemical methods. Similar to the observations of Taylor and Wasserman (1970) we found fluorescence on the surface of the mucosal cells. In addition, we found fluorescence at the basal part of the mucosal cells, which could be ascribed specifically to calciumbinding protein in all cases. The latter localization was not reported by Taylor and Wasserman.

The significance of the localization of calciumbinding protein at the basal and apical poles of the intestinal cells is not apparent from the present studies. Also, the additional finding of the basal localization, which was not reported in the chick, is of interest and is consistent with other studies (Wasserman, 1968a; Wasserman and Taylor, 1968; Piazolo et al, 1974) which suggested a vitamin D effect on calcium transport across both poles of the intestinal cell. All the findings are consistent with the concept that calcium-binding protein may act as a carrier of calcium across the intestinal barrier (Wasserman, 1968b).

In agreement with the findings of Taylor and Wasserman (1970) we found strong fluorescence in goblet cells. However, unlike the results in chicks, this fluorescence still persisted in most cases when 


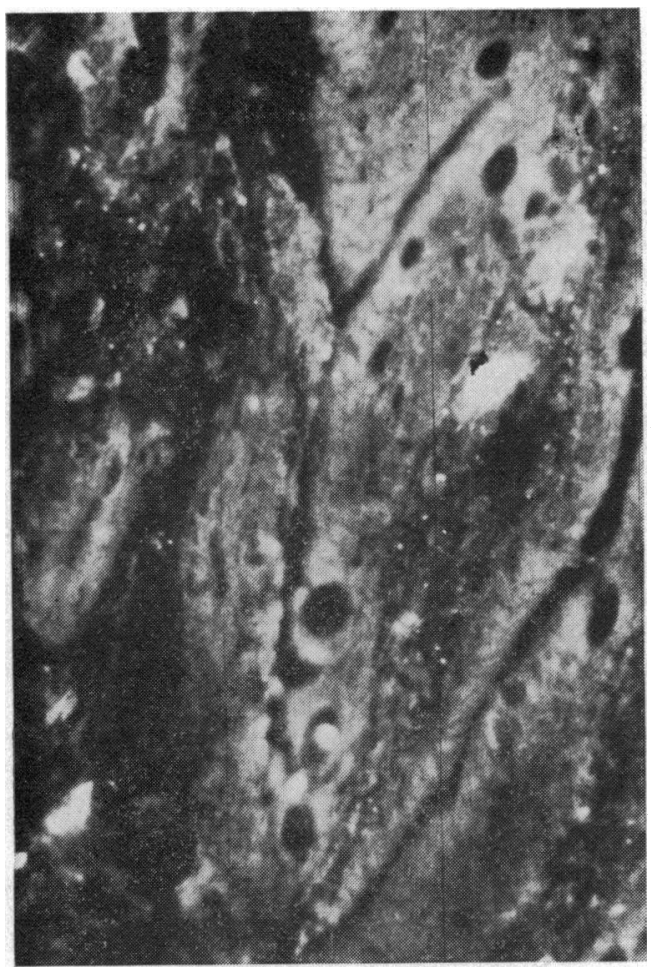

Fig 3a

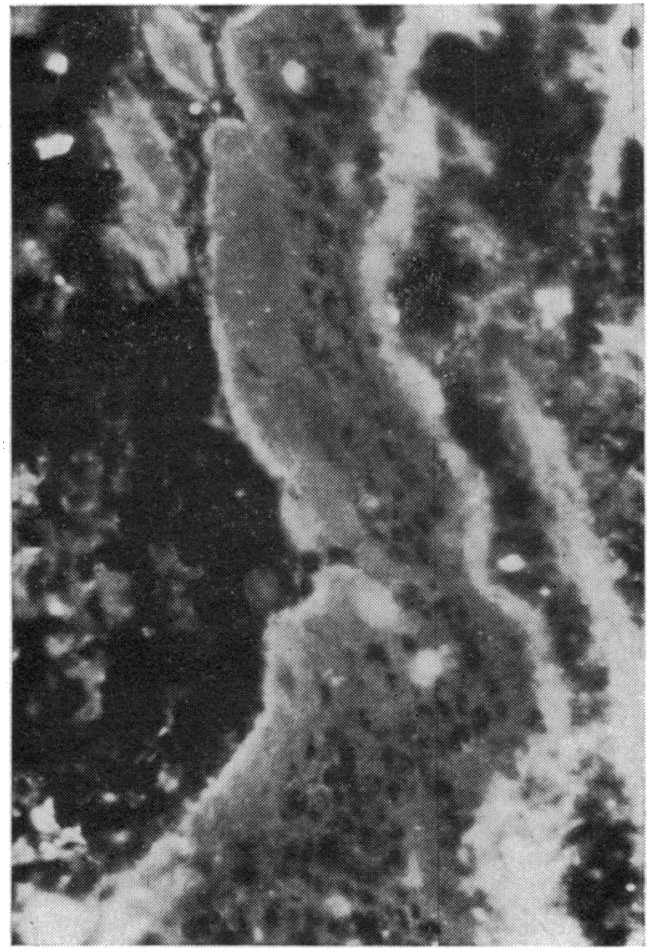

Fig $3 b$

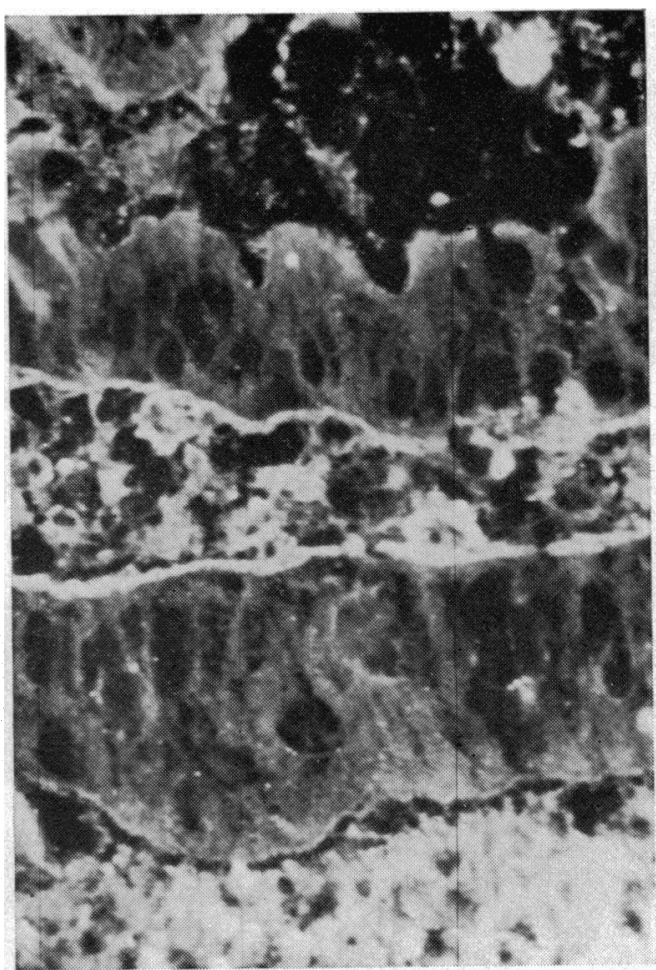

Fig 4

Fig 3a Duodenum of a rachitic child: no specific fluorescence for $\mathrm{CaBP}$ can be seen $(\times 40)$.

Fig 3b After treatment with 25-hydroxycholecalciferol: calcium-binding protein at the apical part of the mucosal cells and at the basement membrane.

Fig 4 Calcium-binding protein in uraemic duodenum: small fluorescent line at the basement membrane only $(\times 63)$. 
calcium-binding protein-adsorbed specific antiserum was employed. Furthermore, the same fluorescence was found after layering the tissue section with sera of non-immunized rabbits and even with the direct method after incubation with a labelled serum against immunoglobulins of the rabbit. Since these results could be obtained with sera of different animal species and antihuman globulin sera, this might mean that the fluorescence is due to an immunoglobulin-like substance. The results cannot be interpreted as a simple affinity for fluorescein stain since layering with labelled antialbumin or pure dissolved fluorescein did not stain the goblet cells. Further studies are needed to identify the nature of this substance. Therefore, nothing definite can be said about the localization of calcium-binding protein in the goblet cells of human intestine.

In summary, with results similar to those of Taylor and Wasserman (1970) in the chick, we were able for the first time to localize calcium-binding protein in human small intestinal tissue. In contrast to the results of Taylor and Wasserman we could not definitely identify calcium-binding protein as being present in the goblet cells. In human tissue, it was found in the basal and apical parts of mucosal cells. This tissue plays an important role in calcium homeostasis and the results of our calcium-binding protein localization studies may assist in ultimately understanding the molecular events involved in these processes.

We thank our technician Miss Bärbel Schäfer for skilful assistance.

The manuscript was kindly reviewed by Drs Wasserman and Taylor, Department of Physical Biology, Cornell University, Ithaca, NY.

The investigations were supported by Deutsche Forschungsgemeinschaft, grant fr 200/14 (Dr Franz).

\section{References}

Alpers, D. H., Lee, S. W., and Avioli, L. V. (1970). Partial isolation of human duodenal calcium-binding proteins. Clin. Res., 18, 605.

Hitchman, A. J. W., Finlay, J. M., and Harrison, J. E. (1971). A study of calcium binding proteins in human and animal small bowel mucosa. In Cellular Mechanisms for Calcium Transfer and Homeostasis, edited by G. Nichols, and R. H. Wasserman Jr., pp. 503-504. Academic Press, New York and London.

Kallfelz, F. A., Taylor, A. N., and Wasserman, R. H. (1967). Vitamin D-induced calcium binding factor in rat intestinal mucosa. Proc. Soc. exp. Biol. (N.Y.), 125, 54-58.

MacGregor, R. R., Hamilton, J. W., and Cohn, D. V. (1971). The induction of calcium-binding protein biosynthesis by vitamin $\mathrm{D}_{3}$ and 25-hydroxycholecalciferol. Clin. Orthop. rel. Res., 78, 83-89.

Mancini, G., Carbonara, A. O., and Heremans, J. F. (1965). Immunochemical quantitation of antigens by single radial immunodiffusion. Immunochemistry, 2, 235-254.

Menczel, J., Eilon, G., Steiner, A., Karaman, C., Mor, E., and Ron, A. (1971). Calcium binding protein in human intestinal mucosa. Israel. J. med. Sci., 7, 396-398.

Ouchterlony, O. (1962)./Diffusion-in-gel methods for immunological analysis. II. Progr. Allergy, 6, 30-154.

Piazolo, P. (1973). Calciumbindendes Protein bei Nierengesunden und niereninsuffizienten Menschen. Habilitationsschrift, Ulm.

Piazolo, P., Schleyer, M., and Franz, H. E. (1971a). Isolierung eines calciumbindenden Proteins aus der menschlichen Niere In Fortschritte der Nephrologie, VII. Symposium der Gesellschaft für Nephrologie, Tübingen, September 1970, edited by A. Bohle and G. E. Schubert, pp. 247-249. Schattauer, Stuttgart and New York.

Piazolo, P., Schleyer, M., and Franz, H. E. (1971b). Isolation and purification of a calcium binding protein from human tissues. Hoppe-Seylers Z. physiol. Chem., 352, 1480-1486.

Piazolo, P., Schleyer, M., Helmke, K., Franz, H. E. (1974). Calcium binding protein from human tissue: isolation, purification, quantification, localization and proof of its vitamin-D-dependency. In Proceedings of the International Symposium on Calcium Binding Proteins, Jablonna, Poland 1973. Elsevier, Amsterdam. (In press.)

Taylor, A. N., and Wasserman, R. H. (1967). Vitamin $D_{8}$ induced calcium-binding protein: partial purification, electrophoretic visualisation and tissue distribution. Arch. Biochem., 119, 536540.

Taylor, A. N., and Wasserman, R. H. (1970). Immuno-fluorescent localization of vitamin $\mathrm{D}$-dependent calcium binding proteins. J. Histochem. Cytochem., 18, 107-115.

Taylor, A. N., Wasserman, R. H., and Jowsey, J. (1968). A vitamin-Ddependent calcium-binding protein in canine intestinal mucosa. Fed. Proc., 27, 675.

Walling, M. W., and Rothman, S. S. (1969). Phosphate-independent, carrier-mediated active transport of calcium by rat intestine. Amer. J. Physiol., 217, 1144-1148.

Wasserman, R. H. (1968a). Calcium transport by the intestine: a model and comment on vitamin $\mathrm{D}$ action. Calc. tiss. Res., 2, 301-313.

Wasserman, R. H. (1968b). Calcium transport by the intestine. Calcif. tiss. Res., $2,301$.

Wasserman, R. H., and Taylor, A. N. (1966). Vitamin $D_{\mathbf{3}}$-induced calcium-binding protein in chick intestinal mucosa. Science, 152, 791-793.

Wasserman, R. H., and Taylor, A. N. (1968). Vitamin-D-dependent calcium binding protein: response to some physiological and nutritional variables. J. biol. Chem., 243, 3987-3993

Wasserman, R. H., and Taylor, A. N. (1970). Evidence for a vitamin $D_{\mathbf{3}}$-induced calcium-binding protein in New World primates. Proc. Soc. exp. Biol. (N.Y.), 136, 25-28. 